\title{
Immunological and immunochemical investigations of patients suffering from general paralysis
}

\author{
HENNING SCHMIDT, E. DEIN, AND E. BOJE RASMUSSEN \\ From the Dermato-venereological Department, Odense County Hospital, \\ and Sct. Hans Mental Hospital, Roskilde, Denmark
}

With the introduction of penicillin treatment for early syphilis, the prognosis for this infection has significantly changed, and it is to be expected that late syphilitic manifestations will become increasingly rare. Even if the period of latency so far allowed for the development of late manifestations is at present too short for a final assessment of penicillin treatment, the action of penicillin in preventing late manifestations has been demonstrated by several workers, including Perdrup (1960), who studied 213 patients who had been given penicillin for primary or secondary syphilis 1 to 11 years previously. It is probable, however, that future cases of late syphilis will occur in patients whose primary symptoms have escaped notice and who have not been given penicillin for other diseases.

With the prospect of general paralysis becoming increasingly rare we thought it timely to examine patients from a mental hospital (Sct. Hans Hospital) by various serological tests and the newer immunochemical methods. These patients all showed typical symptoms and signs of general paralysis, including Argyll Robertson pupils, and the Central Register for syphilitic patients at the State Serum Institute, Copenhagen, supplied case histories. The Register includes nearly all persons diagnosed as syphilitics since 1920 , and also all those who have given positive serological reactions for syphilis, for whatever cause. The Register also gives information on index cards concerning treatment, hospital admissions, etc., but this paper deals only with the present immunological and immunochemical findings in the cases studied.

\section{Material}

The present investigation is based on a total of 32 patients who had repeated tests of serum and cerebrospinal fluid. Provided the amount of fluid was sufficient, the tests included the WassermannMørck complement-fixation test with cardiolipin antigen (WR), the Kahn flocculation test with crude antigen (KR), and the Meinicke flocculation and clarification test with crude antigen (MR). The treponemal immobilization test was performed on all fluids and an immunochemical examination estimating the content of albumin and IgG globulin in the serum and CSF was performed by Dr. Jørgen Clausen, of the Neurochemical Institute, Copenhagen.

The 32 patients included 25 men (average age 64.9 years) and seven women (average age 69.9 years). The numbers were too few to show any difference in immunological patterns between males and females.

Table I compares the reactivity of serum and CSF for STS and TPI. Only 28 patients yielded sufficient material for the STS, but the TPI was performed in all 32 cases. The Table shows that only fourteen of the 28 patients tested by STS had reactive blood or $\mathrm{CSF}$, and twelve had reactive serum only. No patient had reactive CSF and non-reactive serum. Fourteen patients had entirely non-reactive STS. Of the 32 patients tested by the TPI, 28 were reactive; twelve had reactive serum and CSF, sixteen had reactive serum only. The TPI thus showed reactivity in 85 per cent. as compared with only 50 per cent. for STS. STS and TPI gave no information in CSF tests which was not obtained by means of serological examinations.

TABLE I Results of STS and TPI test in serum compared with cerebrospinal fluid

\begin{tabular}{|c|c|c|c|c|c|c|}
\hline Result & $\begin{array}{l}\text { Serum } \\
\text { Cerebrospinal fluid }\end{array}$ & + & $\bar{t}$ & \pm & - & Total cases \\
\hline Test & $\begin{array}{l}\text { STS } \\
\text { TPI }\end{array}$ & $\begin{array}{r}2 \\
12\end{array}$ & $\begin{array}{l}0 \\
0\end{array}$ & $\begin{array}{l}12 \\
16\end{array}$ & $\begin{array}{r}14 \\
4\end{array}$ & $\begin{array}{l}28 \\
32\end{array}$ \\
\hline
\end{tabular}

Table II shows the results of the different STS. In 31 cases the amount of serum was sufficient for

TABLE II $W R$ and $K R$ reactivity in 20 sera nonreactive with $M R$ and 11 sera reactive with $M R$

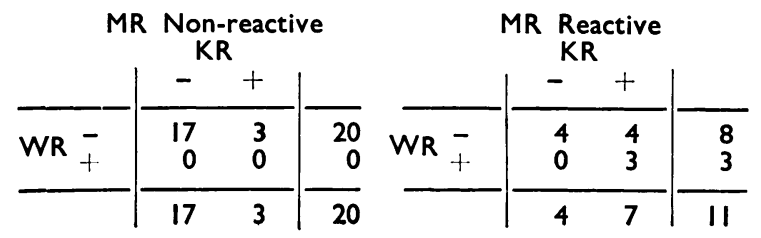


performance of all three tests (WR, KR, and MR). The left-hand diagram shows the reactivity of WR and $K R$ in twenty sera non-reactive to $M R$; three of these sera were reactive by the $K R$, the remaining seventeen being non-reactive by both WR and KR. The MR was reactive in eleven patients; four of these sera were reactive by the $K R$ and three were reactive by both WR and KR. Thus the MR was the most sensitive serum test in this group of patients.

Table III shows the relation between TPI reactivity and that of STS in serum from 31 patients. In four cases the TPI was non-reactive and the STS were reactive in one of them. In five cases the TPI was weakly reactive and the STS were reactive in one of them. Out of 22 TPI-reactive sera, thirteen were STS-reactive. There was thus a significant relationship between the reactivity of TPI and that of STS.

TABLE III Results of TPI test compared with STS in serum from 31 patients

\begin{tabular}{|c|c|c|c|c|}
\hline$T P I$ & Non-reactive & Weakly-reactive & Reactive & Total \\
\hline $\begin{array}{ll}\text { STS } & -\end{array}$ & $\begin{array}{l}3 \\
1\end{array}$ & $\begin{array}{l}4 \\
1\end{array}$ & $\begin{array}{r}9 \\
13\end{array}$ & $\begin{array}{l}16 \\
15\end{array}$ \\
\hline Total & 4 & 5 & 22 & 31 \\
\hline
\end{tabular}

Table IV shows that in the CSF the relationship between TPI and STS findings was similar: there was no STS reactivity in eighteen specimens in which the TPI was non-reactive, no STS reactivity in six in which the TPI was weakly reactive, and two specimens showed STS reactivity out of five in which the TPI was reactive.

TABLE IV Results of TPI test compared with STS in cerebrospinal fluid from 29 patients

\begin{tabular}{|c|c|c|c|c|}
\hline$T P I$ & Non-reactive & Weakly-reactive & Reactive & Total \\
\hline STS & $\begin{array}{r}18 \\
0\end{array}$ & $\begin{array}{l}6 \\
0\end{array}$ & $\begin{array}{l}3 \\
2\end{array}$ & $\begin{array}{r}27 \\
2\end{array}$ \\
\hline Total & 18 & 6 & 5 & 29 \\
\hline
\end{tabular}

Table V shows the reactivity of the TPI in CSF and serum, and here too there was an association between the reactivity to this test in the two fluids.

TABLE $\mathrm{v}$ Reactivity of TPI in serum and cerebrospinal fluid from 32 patients

\begin{tabular}{|c|c|c|c|c|}
\hline $\begin{array}{l}\text { Cerebrospinal } \\
\text { fluid }\end{array}$ & Non-reactive & $\begin{array}{l}\text { Weakly- } \\
\text { reactive }\end{array}$ & Reactive & Total \\
\hline $\begin{array}{c}\text { Serum: Non-reactive } \\
\text { Weakly-reactive } \\
\text { Reactive }\end{array}$ & $\begin{array}{r}4 \\
6 \\
10\end{array}$ & $\begin{array}{l}0 \\
0 \\
6\end{array}$ & $\begin{array}{l}0 \\
0 \\
6\end{array}$ & $\begin{array}{r}4 \\
6 \\
22\end{array}$ \\
\hline Total & 20 & 6 & 6 & 32 \\
\hline
\end{tabular}

The quantities of IgG globulins and albumin in both serum and CSF were estimated. It must be remembered that these immunochemical methods have no immunological specificity. For CSF the normal range of albumin is about $16.9 \mathrm{mg} . / 100 \mathrm{ml}$. $( \pm 1 \cdot 5)$, but the specimens from patients suffering from general paralysis contained an average of $21.6 \mathrm{mg} . / 100 \mathrm{ml}$. In patients suffering from nonsyphilitic diseases the IgG globulin content has been found to be about $1.08 \mathrm{mg}$. $/ 100 \mathrm{ml}$., but in our series of cases the average IgG globulin content was $4 \cdot 17 \mathrm{mg} . / 100 \mathrm{ml}$.

In the serum the content of IgG globulin and albumin was found to be normal. The increased albumin content in the CSF points towards a damaged blood-CSF barrier; the increased concentration of IgG globulin in CSF must be ascribed either to a damaged blood-CSF barrier or to the production of immunoglobulins inside the central nervous system itself.

Dewhurst (1968) reported on the serological findings in 86 patients with neurosyphilis in whom both CSF and serum were tested. He found both the $\mathrm{CSF}$ and the serum tests reactive in 73 cases. In ten cases serum tests were reactive and CSF tests negative, and in three CSF tests were reactive, but serum tests negative. He therefore considered that if neurosyphilis is suspected the CSF should be examined even if the patient is sero-negative. This is not in accordance with our results for STS and TPI, but our immunochemical results point quite clearly to a grossly abnormal content of IgG and albumin in the CSF in neurosyphilis.

A review of the previous treatment of these cases will form the subject of a future report, but at the present time it is stressed that no patient in this study had received penicillin in the early stages of syphilis.

\section{Summary}

In 32 patients suffering from general paralysis, STS were reactive in only half, whereas TPI was reactive in the serum in nearly 90 per cent. It is stressed that CSF examinations must be carried out, but in this series they revealed no positive reactions beyond those disclosed by tests of the serum.

Of the STS, the MR showed the most reactivity. If the serum was reactive to the TPI, it was probable that the CSF would be reactive also.

Immunochemical examinations of CSF showed a pathological amount of IgG globulin and of albumin in cases of general paralysis. 


\section{References}

Dewhurst, K. (1968). F. Neurol. Neurosurg. Psychiat., 31, 496.

Perdrup, A. (1960). Acta derm.-venereol. (Stockh.), 40, 340.

\section{Recherche immunologique et immunochimique chez des malades atteints de paralysie générale}

\section{SOMMAIRE}

Chez 32 malades atteints de paralysie générale, les réactions sérologiques classiques furent positives dans la moitié des cas seulement, alors que le T.I.T. était positif dans le sérum, dans presque 90 pour cent de ces cas. On souligne que l'examen du L.C.R. doit être effectué mais, dans cette série, les réponses ne furent pas plus souvent positives que dans le sérum.

Parmi les réactions classiques, c'est la réaction de Wassermann qui fut le plus souvent positive. Si le T.I.T. est positif dans le sérum, il est probable qu'il le sera aussi dans le L.C.R.

Les examens immunochimiques du L.C.R. montrèrent des chiffres pathologiques de globuline IgG et d'albumine en cas de paralysie générale. 